\title{
Neglect and psychological abuse of older adults in a Brazilian state: analysis of reports between 2011 and 2018
}

Objective: to identify the prevalence of neglect and psychological abuse of older adults and their associations with the characteristics of the victim, the aggressor and the type of aggression in Espírito Santo, Brazil. Method: a cross-sectional study, with data on reports of neglect and psychological abuse of older adults registered in the Espírito Santo Reports of Disease and Harm Information System between 2011-2018. Analyzes were conducted according to the type of abuse and the independent variables were composed of the characteristics of the victim, the aggressor and the type of aggression. For multivariate analysis, Poisson Regression with robust variance was used. Results: during the study period, 296 cases of neglect (18,1\%; CI95\%: 16,31-20,04) and 193 cases of psychological abuse $(11,8 \%$; CI95\%: 10,32-13,46) were reported. Neglect was more prevalent against older adults aged 80 years and over, who were black, had a partner, and were disabled, and was often committed by the victim's son(s) or daughter(s), in their home, in urban areas, in an unmotivated and chronic manner. Psychological abuse was associated with women, perpetrated by men, after alcohol consumption, motivated by intolerance, in the urban area and carried out in a chronic manner. Conclusion: the characteristics of the victim, aggressor and aggression were associated with the occurrence of negligence and psychological abuse differently for each type of abuse. Such abuse is often committed in a veiled manner, and thus goes underreported. It is believed that with the diffusion of knowledge and the carrying out of new studies will contribute to the confrontation, monitoring and prevention of this disease.

\footnotetext{
Universidade Federal do Espírito Santo, Departamento de Ciências da Saúde, Programa de Pós-Graduação em Saúde Coletiva.

2 Escola Superior de Ciências da Santa Casa de Misericórdia, Departamento de Fisioterapia. Vitória, ES, Brasil.
}

Keywords: Violence. Elder Abuse. Health of the Elderly. Mandatory Reporting. Information Systems.

The authors declare there are no conflicts of interest in relation to the present study.

No funding was received in relation to the present study. 


\section{INTRODUCTION}

Abuse of older adults can be subdivided into the categories of physical, psychological, sexual, financial abuse or neglect, and conceptually refers to any type of single or repeated action which results in injury or suffering to older adults ${ }^{1}$. Abuse can also be understood as visible, when it causes deaths or physical injuries, or invisible, when it does not cause apparent injuries ${ }^{2}$.

According to the World Health Organization (WHO), abuse is responsible for low quality of life, emotional disorders, psychological stress, isolation, injuries and physical trauma, in addition to increasing the risk of hospital admissions or stays in nursing homes, which may result in death ${ }^{1}$.

Neglect is defined as the refusal, omission or insufficiency of adequate primary care, such as food and health care, provided to older adults by family members, caregivers, legal or institutional guardians. Psychological abuse, meanwhile, is conceptually any act of verbal or gestural aggression that provokes emotional suffering, distress and anguish in older adults, in addition to exaggerated demands and humiliating punishments ${ }^{3}$.

The worldwide prevalence of abuse against older adults is between 14.3 and $15.7 \%$, varying considerably according to the type of injury $y^{4.5}$. It can be noted that $11.6 \%$ of attacks are psychological and $4.2 \%$ involve neglect ${ }^{5}$. In Brazilian state capitals, the prevalence of abuse against older adults varies from $12.4 \%$ to $14.4 \% 0^{6.7}$, with psychological abuse being the most frequent, representing $10.7 \%$ of cases ${ }^{7}$.

When analyzing reported cases in Brazil, psychological abuse and neglect are always among the main types of recorded abuse, commonly preceded by physical violence ${ }^{8.9}$. The epidemiological bulletin published by the Ministry of Health in 2013, which provided data on abuse against older adults in Brazil, highlighted psychological abuse and neglect, with frequencies of $29 \%$ and $28 \%$, respectively ${ }^{10}$.

Despite the expressive numbers, it is worth mentioning that, as stated by the WHO, abuse against older adults is much more intense and present in society than can be recorded by statistics. It is estimated that throughout the world, only 1 in 24 cases of abuse against older adults are reported ${ }^{11}$. It should be highlighted that, often, the feelings of guilt and shame of the mistreated older adult, associated with the fear of retaliation and reprisal on the part of the aggressor, prevent victims from reporting the abuse suffered ${ }^{2}$.

In view of the above, and bearing in mind the importance of revealing abuse against older adults, in order to contribute to a better understanding of the problem and consequently assist in preventing and tackling it, the present study aimed to identify the prevalence of neglect and psychological abuse against older adults and the association with the characteristics of the victim, the aggressor and the aggression, in the state of Espírito Santo, Brazil.

\section{METHODS}

An epidemiological, analytical cross-sectional study was conducted, using data from reports of abuse against older adults recorded in the Reports of Disease and Harm Information System (or SINAN), in the state of Espírito Santo, Brazil between 2011 and 2018.

Forming part of the southeastern region of Brazil, the state of Espírito Santo has an area of just over $46,000 / \mathrm{Km}^{2}$ and around 3.9 million inhabitants. Divided into 78 municipalities, mostly small and medium sized, the state has undergone a notable change in the age structure of its population, with a significant growth in the older adult population, a phenomenon also observed in Brazil as a whole ${ }^{12}$.

The selection of the period for the study was due to the fact that, as of 2011, abuse became part of the list of conditions of compulsory notification ${ }^{13}$. Monitoring of cases of abuse is carried out through the Notification/Investigation Form for Interpersonal and Self-Harmed Abuse, which contains information regarding the profile of the victim and the aggressor, the characteristics of the abuse and any referrals made. This form is filled out by the various notifying sources, including health services, with two copies, one of which remains with the notifying sector and the other with the sector responsible for the Epidemiological Surveillance of the municipality, where the data are entered into the system and later 
transferred to state and federal levels, to form part of the national database ${ }^{14}$.

The study population is composed of all cases of psychological abuse and neglect practiced against individuals aged 60 years or over, reported in the state of Espírito Santo, between the years 2011 and 2018. In order to carry out statistical analyzes, the database underwent careful exploratory analysis, following the guidelines of the Instructions for Interpersonal and Self-Harmed Abuse Notification ${ }^{14}$, to correct possible errors and inconsistencies.

As outcomes under study, two types of interpersonal abuse were analyzed: psychological (yes/no) and neglect (yes/no). The independent variables were: characteristics of the victim - age (60 to 69 years/ 70 to 79 years/80 years or more), sex (male/female), skin color/ethnicity (white/black/ mixed ethnicity), education ( 0 to 4 years $/ 5$ to 8 years/ 9 years or more), marital status (with partner/ without partner) and presence of disability/disorder (yes/no); characteristics of the aggressor - age in years (0 to $19 / 20$ to $59 / 60$ or more), sex (male/female/ both), relationship (children/partners/others) and suspected alcohol use (yes/no); characteristics of the aggression - number of people involved (one/two or more), if abuse occurred in the residence (yes/ no), at what time of day (morning/afternoon/night/ early hours), if there was a history of repetition (yes/ no), zone where abuse occurred (urban or rural), motivated by hate (yes/no) and referrals (yes/no).

The data were analyzed using descriptive statistics in crude and relative frequencies and their 95\% confidence intervals. Bivariate analyzes were performed using the Chi-square test, with a significance level of $p<0.05$. The association between the variables was tested using Poisson regression with robust variance expressed in gross and adjusted Prevalence Ratios (PR), and the respective 95\% confidence intervals. For adjusted analysis, entry into the model occurred with a value of $p<0.20$ and permanence with $p<0.05$. Adjusted analysis occurred with the entry in the model at two levels, the first of which included data about the victim and the second the other variables.
The study was approved by the Research Ethics Committee of the Universidade Federal do Espírito Santo (the Federal University of Espírito Santo), under opinion number 2,819,597, and all the rules and guidelines of Resolutions 466/2012 and 510/2016 of the National Health Council were respected.

\section{RESULTS}

Between 2011 and 2018, there were notifications of 1,635 cases of interpersonal abuse against older adults. Approximately one third of these notifications ( $\mathrm{N}=489$ cases) were of psychological abuse and neglect. Neglect-type abuse was observed as the second most reported in the state $(\mathrm{n}=296 ; 18.1 \%$; 95\% CI: 16.31-20.04), followed by psychological abuse ( $\mathrm{n}=193 ; 11.8 \%$; 95\% CI: 10.32-13.46) (data not shown in table).

The studied population consisted mostly of older adults aged 80 or over, female, white, with low levels of education (0 to 4 years), with a partner and without disabilities. The aggressors were mostly in the 20-59 age group, male, a child of the victim and without suspected use of alcohol at the time of the abuse. Most of the occurrences involved an aggressor, with the residence being the main place of abuse. Most cases took place in the morning, with a history of repetition and in an urban area. It can be seen that in large part there was no motivation of hate and the cases were referred for follow-up in responsible sectors (Table 1).

Regarding the bivariate analysis, it can be observed that the studied abuse was related to the variables of skin color/ethnicity, education, age and sex of the aggressor, relationship, place of occurrence, history of repetition and motivation $(p<0.05)$. It is also noted that only neglect was related to the variables: age, marital status, disability/disorder, suspected alcohol use, number of people involved, time of day and area of occurrence. The variable sex of the victim was related only to psychological abuse $(p<0.05)$ (Table 2). 
Table 1. Characterization of the reported cases of psychological abuse and neglect against older adults, according to data regarding the victim, the aggressor and the occurrence. Espírito Santo, 2011-2018.

\begin{tabular}{|c|c|c|}
\hline Variables & $\mathrm{n}(\%)$ & $(95 \% \mathrm{CI})$ \\
\hline \multicolumn{3}{|l|}{ Age (years) } \\
\hline 60 to 69 & $165(33.7)$ & $29,5-38,0$ \\
\hline 70 to 79 & $152(31.1)$ & $27,2-35,0$ \\
\hline 80 or over & $172(35.2)$ & $30,9-39,5$ \\
\hline \multicolumn{3}{|l|}{ Sex } \\
\hline Male & $145(29.7)$ & $25,8-33,7$ \\
\hline Female & $344(70.3)$ & $66,3-74,2$ \\
\hline \multicolumn{3}{|c|}{ Skin color/ethnicity } \\
\hline White & $205(46.8)$ & $42,0-51,6$ \\
\hline Black & $76(17.4)$ & $13,9-21,0$ \\
\hline Mixed ethnicity & $157(35.8)$ & $31,5-40,2$ \\
\hline \multicolumn{3}{|l|}{ Schooling (years) } \\
\hline 0 to 4 & $184(63.7)$ & $57,8-68,9$ \\
\hline 5 to 8 & $34(11.8)$ & $8,3-15,9$ \\
\hline 9 or more & $71(24.6)$ & $19,4-29,4$ \\
\hline \multicolumn{3}{|l|}{ Marital status } \\
\hline Partner & $274(67.5)$ & $62,8-71,9$ \\
\hline No partner & $132(32.5)$ & $28,1-37,2$ \\
\hline \multicolumn{3}{|c|}{ Disability/Disorder } \\
\hline Yes & $162(41.1)$ & $36,3-46,2$ \\
\hline No & $232(58.9)$ & $53,8-63,7$ \\
\hline \multicolumn{3}{|c|}{ Age of aggressor (years) } \\
\hline 0 to 19 & $04(1.4)$ & $0,3-2,7$ \\
\hline 20 to 59 & $223(75.9)$ & $71,1-80,6$ \\
\hline 60 or more & $67(22.8)$ & $18,0-27,5$ \\
\hline \multicolumn{3}{|l|}{ Sex of aggressor } \\
\hline Male & $197(45.3)$ & $40,2-49,9$ \\
\hline Female & $112(25.7)$ & $21,8-29,7$ \\
\hline Both & $126(29.0)$ & $24,6-33,3$ \\
\hline \multicolumn{3}{|c|}{ Relationship with victim } \\
\hline Child & $225(56.8)$ & $51,8-61,9$ \\
\hline Partners & $69(17.4)$ & $13,9-21,2$ \\
\hline Others & $102(25.8)$ & $21,5-30,3$ \\
\hline \multicolumn{3}{|c|}{ Suspected alcohol use } \\
\hline Yes & $100(33.7)$ & $28,3-39,4$ \\
\hline No & 197 (66.3) & $60,6-71,7$ \\
\hline \multicolumn{3}{|c|}{ Number of aggressors } \\
\hline One & $256(53.8)$ & $49,4-58,0$ \\
\hline Two or more & $220(46.2)$ & $42,0-50,6$ \\
\hline \multicolumn{3}{|c|}{ Did it take place in residence } \\
\hline Yes & $426(93.6)$ & $91,4-95,6$ \\
\hline No & $29(6.4)$ & $4,4-8,6$ \\
\hline
\end{tabular}


Continuation of Table 1

\begin{tabular}{lcc}
\hline Variables & $\mathrm{n}(\%)$ & $(95 \% \mathrm{CI})$ \\
\hline Time of occurrence & $130(47.6)$ & $41,8-53,5$ \\
Morning & $73(26.7)$ & $21,6-32,2$ \\
Afternoon & $44(16.1)$ & $12,1-20,9$ \\
Night & $26(9.5)$ & $6,2-13,2$ \\
Early hours & & \\
Recurrent abuse & $368(89.5)$ & $86,4-92,5$ \\
Yes & $43(10.5)$ & $7,5-13,6$ \\
No & $440(94.0)$ & $91,4-95,5$ \\
Occurrence zone & $28(6.0)$ & $4,5-8,7$ \\
Urban & $113(39.0)$ & $33,4-44,5$ \\
Rural & $177(61.0)$ & $55,5-66,6$ \\
Motivated by hate & & $83,6-89,4$ \\
Yes & $416(86.5)$ & $10,6-16,4$ \\
No & $65(13.5)$ & \\
Referrals & & \\
Yes & & \\
No & & \\
\hline
\end{tabular}

The absolute frequency totals differ due to missing data (blank or ignored in the notification forms).

Table 2. Characterization of the reported cases of psychological abuse and neglect against older adults, according to the data of the victim, the aggressor and the occurrence. Espírito Santo, 2011-2018.

\begin{tabular}{|c|c|c|c|c|c|c|}
\hline \multirow[t]{2}{*}{ Variables } & \multicolumn{3}{|c|}{$\begin{array}{l}\text { Psychological abuse } \\
\mathrm{n}=193\end{array}$} & \multicolumn{3}{|l|}{$\begin{array}{l}\text { Neglect } \\
\mathrm{n}=296\end{array}$} \\
\hline & $\mathrm{n}(\%)$ & CI $95 \%$ & $\mathrm{p}$-value & $\mathrm{n}(\%)$ & CI 95\% & $\mathrm{p}$-value \\
\hline \multicolumn{7}{|l|}{ Age (years) } \\
\hline 60 to 69 & $96(11.5)$ & $9.4-13.7$ & 0.328 & $69(8.2)$ & $6.6-10.3$ & $<0.001$ \\
\hline 70 to 79 & $51(10.9)$ & $8.3-14.0$ & & 101 (21.6) & $18.0-25.4$ & \\
\hline 80 or over & $46(14.2)$ & $10.8-18.4$ & & $126(38.9)$ & $33.7-44.3$ & \\
\hline \multicolumn{7}{|l|}{ Sex } \\
\hline Male & $24(3.8)$ & $2.6-5.6$ & $<0.001$ & $121(19.2)$ & $16.3-22.5$ & 0.338 \\
\hline Female & $169(16.8)$ & $14.6-19.2$ & & $175(17.4)$ & 15.2-19.9 & \\
\hline \multicolumn{7}{|c|}{ Skin color/ethnicity } \\
\hline White & $95(14.7)$ & $12.2-17.7$ & 0.010 & $110(17.1)$ & $14.3-20.2$ & 0.001 \\
\hline Black & $23(12.1)$ & $8.1-17.5$ & & $53(27.8)$ & $21.8-34.5$ & \\
\hline Mixed ethnicity & $57(9.2)$ & $7.1-11.7$ & & $100(16.1)$ & $13.4-19.2$ & \\
\hline \multicolumn{7}{|l|}{ Schooling (years) } \\
\hline 0 to 4 & $74(12.4)$ & $10.0-15.3$ & 0.021 & $110(18.4)$ & $15.5-21.7$ & 0.008 \\
\hline 5 to 8 & $18(11.9)$ & 7.6-18.2 & & $16(10.6)$ & $6.6-16.6$ & \\
\hline 9 or more & $45(19.6)$ & $14.9-25.2$ & & $26(11.3)$ & $7.8-16.1$ & \\
\hline \multicolumn{7}{|l|}{ Marital status } \\
\hline Partner & $104(13.4)$ & $11.2-16.0$ & 0.595 & $170(21.9)$ & $19.1-25.0$ & $<0.001$ \\
\hline No partner & $71(12.4)$ & $10.0-15.4$ & & $61(10.7)$ & $8.4-13.5$ & \\
\hline
\end{tabular}


Continuation of Table 2

\begin{tabular}{|c|c|c|c|c|c|c|}
\hline \multirow[t]{2}{*}{ Variables } & \multicolumn{3}{|c|}{$\begin{array}{l}\text { Psychological abuse } \\
\mathrm{n}=193\end{array}$} & \multicolumn{3}{|l|}{$\begin{array}{l}\text { Neglect } \\
\mathrm{n}=296\end{array}$} \\
\hline & $\mathrm{n}(\%)$ & CI 95\% & p-value & $\mathrm{n}(\%)$ & CI 95\% & p-value \\
\hline \multicolumn{7}{|c|}{ Disability/Disorder } \\
\hline Yes & $46(15.3)$ & $11.7-19.9$ & 0.093 & $116(38.7)$ & $33.3-44.3$ & $<0.001$ \\
\hline No & $124(11.7)$ & $9.9-13.8$ & & $108(10.2)$ & $8.5-12.1$ & \\
\hline \multicolumn{7}{|c|}{ Age of aggressor (years) } \\
\hline 0 to 19 & $04(10.3)$ & $3.8-24.6$ & 0.005 & - & - & 0.017 \\
\hline 20 to 59 & $100(13.1)$ & $10.9-15.7$ & & $123(16.1)$ & 13.7-18.9 & \\
\hline 60 or more & $37(22.7)$ & $16.9-29.8$ & & $30(18.4)$ & $13.2-25.1$ & \\
\hline \multicolumn{7}{|c|}{ Sex of aggressor } \\
\hline Male & $132(14.3)$ & $12.2-16.7$ & 0.037 & $65(7.0)$ & $5.6-8.9$ & $<0.001$ \\
\hline Female & $31(8.9)$ & $6.3-12.3$ & & $81(23.3)$ & $19.0-27.9$ & \\
\hline Both & $24(13.5)$ & $9.2-19.4$ & & $102(57.3)$ & $49.9-64.4$ & \\
\hline \multicolumn{7}{|c|}{ Relationship with victim } \\
\hline Child & $73(14.3)$ & $11.5-17.6$ & $<0.001$ & $152(29.7)$ & $25.9-33.8$ & 0.001 \\
\hline Partners & $53(20.8)$ & $16.2-26.2$ & & $16(6.3)$ & $3.9-10.0$ & \\
\hline Others & $43(7.0)$ & $5.1-9.2$ & & $59(9.5)$ & $7.4-12.1$ & \\
\hline \multicolumn{7}{|c|}{ Suspected alcohol use } \\
\hline Yes & $73(16.5)$ & $13.3-20.3$ & 0.059 & $27(6.1)$ & $4.2-8.8$ & $<0.001$ \\
\hline No & $69(12.3)$ & $9.8-15.3$ & & $128(22.8)$ & $19.5-26.5$ & \\
\hline \multicolumn{7}{|c|}{ Number of aggressors } \\
\hline One & $136(12.7)$ & $10.9-14.9$ & 0.491 & $120(11.2)$ & $9.5-13.2$ & $<0.001$ \\
\hline Two or more & $53(11.5)$ & $8.9-14.7$ & & $167(36.2)$ & $31.9-40.6$ & \\
\hline \multicolumn{7}{|c|}{ Did it take place in residence } \\
\hline Yes & $170(14.2)$ & $12.3-16.2$ & $<0.001$ & $256(21.3)$ & $19.1-23.7$ & $<0.001$ \\
\hline No & $13(4.9)$ & $2.9-8.3$ & & $16(6.1)$ & $3.8-9.7$ & \\
\hline \multicolumn{7}{|c|}{ Time of occurrence } \\
\hline Morning & $41(13.8)$ & $10.3-18.2$ & 0.164 & $89(29.9)$ & $24.9-35.3$ & $<0.001$ \\
\hline Afternoon & $31(10.4)$ & $7.4-14.4$ & & $42(14.1)$ & $10.6-18.5$ & \\
\hline Night & $25(8.1)$ & $5.5-11.7$ & & $19(6.2)$ & $4.0-9.5$ & \\
\hline Early hours & $13(11.5)$ & $6.8-18.9$ & & $13(11.5)$ & $6.8-18.9$ & \\
\hline \multicolumn{7}{|c|}{ Recurrent abuse } \\
\hline Yes & $158(19.3)$ & $16.7-22.1$ & $<0.001$ & $210(25.6)$ & $22.7-28.7$ & $<0.001$ \\
\hline No & $18(3.4)$ & $2.2-5.4$ & & $25(4.8)$ & $3.2-7.0$ & \\
\hline \multicolumn{7}{|c|}{ Occurrence zone } \\
\hline Urban & $172(12.9)$ & $11.2-14.8$ & 0.055 & $268(20.1)$ & $18.0-22.3$ & $<0.001$ \\
\hline Rural & $15(8.0)$ & $5.4-13.5$ & & $13(6.9)$ & $4.2-11.7$ & \\
\hline \multicolumn{7}{|c|}{ Motivated by hate } \\
\hline Yes & 75 (18.7) & $15.2-22.8$ & $<0.001$ & $38(9.5)$ & $7.0-12.8$ & $<0.001$ \\
\hline No & $41(8.9)$ & $6.6-11.8$ & & $136(29.5)$ & $23.5-33.8$ & \\
\hline \multicolumn{7}{|l|}{ Referrals } \\
\hline Yes & $161(12.1)$ & 10.4-13.9 & 0.885 & $255(19.1)$ & $17.1-21.3$ & 0.177 \\
\hline No & $29(12.4)$ & $8.7-17.3$ & & $36(15.4)$ & $11.2-20.6$ & \\
\hline
\end{tabular}

Test: Pearson's chi-squared 
After adjusted analysis, it can be seen in Table 3 that the prevalence of psychological abuse was 4.28 times higher in older women (PR: 4.28; 95\% CI: 2.77-6.61), and most frequently carried out by men (PR: 2.92; 95\% CI: 1.11-7.71), with suspected alcohol use (PR: 1.55; 95\% CI: 1.05-2.29). Psychological abuse was more prevalent in the group with a history of recurrent abuse (PR: 4.31; 95\% CI: 1.86-9.95), reported in urban areas (PR: 4.06; 95\% CI: 1.05 -15.7) and motivated by hate (PR: 1.78; 95\% CI: 1.18-2.70).

Table 3. Crude and adjusted analysis of the effects of the characteristics of the victim, the aggressor and the occurrence on the psychological abuse practiced against older adults. Espírito Santo, 2011-2018.

\begin{tabular}{|c|c|c|c|c|c|c|}
\hline \multirow{2}{*}{ Variables } & \multicolumn{3}{|c|}{ Crude Analysis } & \multicolumn{3}{|c|}{ Adjusted Analysis } \\
\hline & $\mathrm{RP}$ & CI $95 \%$ & p-value & PR & CI 95\% & $\mathrm{p}$-value \\
\hline \multicolumn{7}{|l|}{ Sex } \\
\hline Male & 1.0 & & $<0.001$ & 1.0 & & $<0.001$ \\
\hline Female & 4.40 & $2.90-6.67$ & & 4.28 & $2.77-6.61$ & \\
\hline \multicolumn{7}{|c|}{ Skin color/ethnicity } \\
\hline White & 1.0 & & 0.011 & 1.0 & & 0.247 \\
\hline Black & 0.82 & $0.54-1.26$ & & 0.71 & $0.40-1.29$ & \\
\hline Mixed ethnicity & 0.62 & $0.46-0.85$ & & 0.76 & $0.53-1.10$ & \\
\hline \multicolumn{7}{|l|}{ Education (years) } \\
\hline 0 to 4 & 1.0 & & 0.019 & 1.0 & & 0.225 \\
\hline 5 to 8 & 0.96 & $0.59-1.56$ & & 0.91 & $0.54-1.52$ & \\
\hline 9 or more & 1.58 & $1.13-2.22$ & & 1.33 & $0.92-1.91$ & \\
\hline \multicolumn{7}{|c|}{ Disability / Disorder } \\
\hline Yes & 1.31 & $0.96-1.79$ & 0.090 & 1.24 & $0.90-1.72$ & 0.194 \\
\hline No & 1.0 & & & 1.0 & & \\
\hline \multicolumn{7}{|c|}{ Aggressor's age (years) } \\
\hline 0 to 19 & 1.0 & & 0.004 & 1.0 & & 0.604 \\
\hline 20 to 59 & 1.28 & $0.50-3.30$ & & 0.69 & $0.27-1.75$ & \\
\hline 60 or more & 2.21 & $0.84-5.85$ & & 0.80 & $0.30-2.13$ & \\
\hline \multicolumn{7}{|c|}{ Sex of the aggressor } \\
\hline Male & 1.06 & $0.71-1.59$ & 0.044 & 2.92 & $1.11-7.71$ & 0.048 \\
\hline Female & 0.66 & $0.40-1.09$ & & 1.86 & $0.64-5.44$ & \\
\hline Both & 1.0 & & & 1.0 & & \\
\hline \multicolumn{7}{|c|}{ Relationship with the victim } \\
\hline Child & 2.05 & $1.44-2.94$ & $<0.001$ & 1.12 & $0.54-2.33$ & 0.902 \\
\hline Partner & 2.99 & $2.06-4.35$ & & 1.0 & $0.46-2.21$ & \\
\hline Others & 1.0 & & & 1.0 & & \\
\hline \multicolumn{7}{|c|}{ Suspected alcohol use } \\
\hline Yes & 1.34 & $0.99-1.82$ & 0.059 & 1.55 & $1.05-2.29$ & 0.027 \\
\hline No & 1.0 & & & 1.0 & & \\
\hline \multicolumn{7}{|c|}{ Abuse took place at the residence } \\
\hline Yes & 2.87 & $1.66-4.96$ & $<0.001$ & 1.21 & $0.54-2.71$ & 0.636 \\
\hline No & 1.0 & & & 1.0 & & \\
\hline
\end{tabular}


Continuation of Table 3

\begin{tabular}{|c|c|c|c|c|c|c|}
\hline \multirow{2}{*}{ Variables } & \multicolumn{3}{|c|}{ Crude Analysis } & \multicolumn{3}{|c|}{ Adjusted Analysis } \\
\hline & $\mathrm{RP}$ & CI 95\% & $\mathrm{p}$-value & PR & CI $95 \%$ & $\mathrm{p}$-value \\
\hline \multicolumn{7}{|c|}{ Time of occurrence } \\
\hline Morning & 1.20 & $0.67-2.15$ & 0.171 & 1.29 & $0.54-3.08$ & 0.929 \\
\hline Afternoon & 0.90 & $0.49-1.66$ & & 1.29 & $0.53-3.11$ & \\
\hline Night & 0.71 & $0.37-1.33$ & & 1.15 & $0.50-2.67$ & \\
\hline Early hours & 1.0 & $0.47-1.50$ & & 1.0 & $0.47-1.50$ & \\
\hline \multicolumn{7}{|c|}{ Recurrent abuse } \\
\hline Yes & 5.61 & $3.49-9.02$ & $<0.001$ & 4.31 & $1.86-9.95$ & $<0.001$ \\
\hline No & 1.0 & & & 1.0 & & \\
\hline \multicolumn{7}{|c|}{ Occurrence zone } \\
\hline Urban & 1.62 & $0.97-2.68$ & 0.063 & 4.06 & $1.05-15.7$ & 0.043 \\
\hline Rural & 1.0 & & & 1.0 & & \\
\hline \multicolumn{7}{|c|}{ Motivated by hate } \\
\hline Yes & 2.10 & $1.47-3.00$ & $<0.001$ & 1.78 & $1.18-2.70$ & 0.007 \\
\hline No & 1.0 & & & 1.0 & & \\
\hline
\end{tabular}

Teste: Poisson regression with robust variance; PR: prevalence ratio.

Neglect-type abuse, after adjusting for confounding factors, proved to be 4.58 times more prevalent among older people aged 80 and over than younger older people (60 to 69 years old), $45.0 \%$ more frequent in black people than those of mixed ethnicity, $42.0 \%$ higher among those with a partner, and 3.24 times more prevalent in older adults with some type of disability/disorder.

Table 4. Crude and adjusted analysis of the effects of the characteristics of the victim, the aggressor and the occurrence on the psychological abuse practiced against older adults person. Espírito Santo, 2011-2018.

\begin{tabular}{|c|c|c|c|c|c|c|}
\hline \multirow{2}{*}{ Variables } & \multicolumn{3}{|c|}{ Crude Analysis } & \multicolumn{3}{|c|}{ Adjusted Analysis } \\
\hline & PR & $(95 \% \mathrm{CI})$ & p-value & PR & $(95 \% \mathrm{CI})$ & p-value \\
\hline \multicolumn{7}{|l|}{ Age (years) } \\
\hline 60 to 69 & 1.0 & & $<0.001$ & 1.0 & & $<0.001$ \\
\hline 70 to 79 & 2.62 & $1.97-3.48$ & & 2.78 & $1.94-3.99$ & \\
\hline 80 or more & 4.72 & $3.62-6.14$ & & 4.58 & $3.22-6.51$ & \\
\hline \multicolumn{7}{|c|}{ Skin color/ethnicity } \\
\hline White & 1.06 & $0.83-1.36$ & 0.001 & 1.05 & $0.78-1.41$ & 0.033 \\
\hline Black & 1.73 & $1.29-2.31$ & & 1.45 & $1.08-1.94$ & \\
\hline Mixed ethnicity & 1.0 & & & 1.0 & & \\
\hline \multicolumn{7}{|l|}{ Education (years) } \\
\hline 0 to 4 & 1.0 & & 0.010 & 1.0 & & 0.280 \\
\hline 5 to 8 & 0.58 & $0.35-0.94$ & & 0.85 & $0.49-1.48$ & \\
\hline 9 or more & 0.62 & $0.41-0.92$ & & 0.67 & $0.40-1.11$ & \\
\hline \multicolumn{7}{|l|}{ Marital Status } \\
\hline Partner & 2.05 & $1.56-2.70$ & $<0.001$ & 1.42 & $1.08-1.88$ & 0.013 \\
\hline No partner & 1.0 & & & 1.0 & & \\
\hline
\end{tabular}


Continuation of Table 4

\begin{tabular}{|c|c|c|c|c|c|c|}
\hline \multirow{2}{*}{ Variables } & \multicolumn{3}{|c|}{ Crude Analysis } & \multicolumn{3}{|c|}{ Adjusted Analysis } \\
\hline & PR & $(95 \% \mathrm{CI})$ & p-value & PR & $(95 \% \mathrm{CI})$ & p-value \\
\hline \multicolumn{7}{|c|}{ Disability / Disorder } \\
\hline Yes & 3.80 & $3.02-4.77$ & $<0.001$ & 3.24 & $2.51-4.17$ & $<0.001$ \\
\hline No & 1.0 & & & 1.0 & & \\
\hline \multicolumn{7}{|c|}{ Aggressor's age (years) } \\
\hline 0 to 19 & -- & -- & 0.477 & -- & -- & 0.141 \\
\hline 20 to 59 & 1.0 & & & 1.0 & & \\
\hline 60 or more & 1.14 & $0.79-1.64$ & & 1.49 & $0.88-2.55$ & \\
\hline \multicolumn{7}{|c|}{ Sex of the aggressor } \\
\hline Male & 1.0 & & $<0.001$ & 1.0 & & $<0.001$ \\
\hline Female & 3.31 & $2.45-4.48$ & & 1.89 & $0.95-3.76$ & \\
\hline Both & 8.15 & $6.24-10.63$ & & 3.91 & $2.01-7.58$ & \\
\hline \multicolumn{7}{|c|}{ Relationship with the victim } \\
\hline Children & 3.12 & $2.36-4.11$ & $<0.001$ & 3.0 & $1.45-6.21$ & 0.012 \\
\hline Partners & 0.66 & $0.39-1.12$ & & 1.88 & $0.71-4.98$ & \\
\hline Others & 1.0 & & & 1.0 & & \\
\hline \multicolumn{7}{|c|}{ Suspected alcohol use } \\
\hline Yes & 1.0 & & $<0.001$ & 1.0 & & $<0.001$ \\
\hline No & 3.74 & $2.51-5.56$ & & 2.98 & $1.60-5.57$ & \\
\hline \multicolumn{7}{|c|}{ Number of aggressors } \\
\hline A & 1.0 & & $<0.001$ & 1.0 & & 0.596 \\
\hline Two or more & 3.22 & $2.61-3.96$ & & 0.81 & $0.37-1.77$ & \\
\hline \multicolumn{7}{|c|}{ Abuse took place at the residence } \\
\hline Yes & 3.51 & $2.15-5.70$ & $<0.001$ & 3.31 & $1.51-7.55$ & 0.003 \\
\hline No & 1.0 & & & 1.0 & & \\
\hline \multicolumn{7}{|c|}{ Time of occurrence } \\
\hline Morning & 2.60 & $1.51-4.46$ & $<0.001$ & 1.04 & $0.47-2.31$ & 0.479 \\
\hline Afternoon & 1.22 & $0.68-2.20$ & & 0.68 & $0.30-1.84$ & \\
\hline Night & 0.54 & $0.27-1.05$ & & 0.49 & $0.26-2.46$ & \\
\hline Early hours & 1.0 & & & 1.0 & & \\
\hline \multicolumn{7}{|c|}{ Recurrent Violence } \\
\hline Yes & 5.36 & $3.59-7.99$ & $<0.001$ & 3.82 & $1.74-8.39$ & 0.001 \\
\hline No & 1.0 & & & 1.0 & & \\
\hline \multicolumn{7}{|c|}{ Occurrence zone } \\
\hline Urban & 2.90 & $1.70-4.96$ & $<0.001$ & 3.05 & $1.53-6.08$ & 0.001 \\
\hline Rural & 1.0 & & & 1.0 & & \\
\hline \multicolumn{7}{|c|}{ Motivated by hate } \\
\hline Yes & 1.0 & & $<0.001$ & 1.0 & & $<0.001$ \\
\hline No & 3.11 & $2.23-4.35$ & & 2.97 & $1.85-4.79$ & \\
\hline \multicolumn{7}{|l|}{ Referrals } \\
\hline Yes & 1.24 & $0.90-1.71$ & $<0.001$ & 1.42 & $0.58-3.49$ & 0.442 \\
\hline No & 1.0 & & & 1.0 & & \\
\hline
\end{tabular}

Test: Poisson regression with robust variance; PR: prevalence ratio. 
In relation to the aggressors, it is observed that neglect was predominantly committed by individuals of both sexes (PR: 3.91; 95\% CI: 2.01-7.58). Children were often the main aggressors (PR: 3.0; 95\% CI: 1.45-6.21), and there was no suspicion of alcohol abuse at the time of the aggression (PR: 2.98; 95\% CI: 1, 60-5.57). The occurrence of neglect was 3.31 times higher at home, compared to those that occurred in other environments, 3.82 times more of the recurrent abuse type, and 3.0 times more frequent in the urban area, and not motivated by hate (PR: 2.97).

\section{DISCUSSION}

The prevalence of notifications of abuse against older adults in the present study was $11.8 \%$ for psychological abuse and $18.1 \%$ for neglect. A study ${ }^{15}$ that analyzed the reports of abuse against older adults in a state in northeastern Brazil identified a prevalence of $13.3 \%$ of psychological abuse, similar to that found in this study, in contrast to neglect, where the prevalence was $26.6 \%$, higher than that identified in the present study. Mascarenhas et al. ${ }^{8}$, when studying the reported cases of abuse against older adults across Brazil, also identified higher prevalences in both types of abuse. However, it is worth noting that the literature is not cohesive when dealing with these problems, sometimes indicating a higher prevalence of psychological abuse ${ }^{9}$, and sometimes neglect ${ }^{15}$, but always emphasizing the divergence.

It is important to point out that, as stated in the literature, both psychological abuse and neglect are diseases that are difficult to detect, and consequently to be reported, mainly because occur intrinsically within family life, and requiring a close look at health and social services so that they can be identified and notified ${ }^{16.17}$.

Regarding the characteristics of the victim of aggression, studies ${ }^{4.18}$ have shown, among other variables, that functional and cognitive dependence are some of the strongest risk factors for general abuse against older adults, and another study has highlighted these findings with regard to neglect ${ }^{19}$. Considering that the risk of dependence increases with advancing age ${ }^{4.16}$, there is a greater demand for care for older adults, consequently increasing the chances of these individuals being victims of neglect, especially when added to the stress and lack of preparation of caregivers ${ }^{16,18,19}$. This is in line with the findings of the present study, which show that neglect was 4.58 times more prevalent among older people aged 80 and over, compared to those between 60 and 69 years old, and 3.24 times more frequent in older adults with some type of disability or disorder.

With regard to the sex of the victim, it is noted that the prevalence of psychological abuse was 4.28 times higher in women, similar to the study by Ho et $\mathrm{al}^{20}{ }^{20}$, where the authors report that older women are at greater risk of suffering abuse than men. Historically, regardless of the life cycle, women are more vulnerable to abuse and men more likely to perpetrate $\mathrm{it}^{21,22}$.

Reinforcing this point, the present study identified that psychological abuse was three times more frequently committed by men, with $55.0 \%$, and more prevalent among those with suspected alcohol consumption. Previous study findings indicate that women are more frequently abused by $\mathrm{men}^{22}$, and the understanding of this fact results from the analysis of abuse as a product of an unequal society, marked by sexist practices, which are enhanced in the presence of alcohol ${ }^{23}$, giving men the subjective belief that they have the right to exercise power over women, usually through abusive acts that often compromise their psychological conditions ${ }^{22,23}$.

Regarding the victim's skin color/ethnicity, this variable remained associated only with neglect, where this condition was $45.0 \%$ more prevalent in older black people, similar to the results found by Acierno, et al. ${ }^{19}$, when studying almost 6,000 older people in the USA, and revealing a higher prevalence of neglect in older people considered to be non-white. Pillemer, et al. ${ }^{4}$ and Johannesen and LoGiudice ${ }^{24}$ suggest that specific racial groups present divergent risk rates for different types of abuse, indicating the need for studies that seek to elucidate these specific differences.

Another important characteristic of the victim of abuse to be discussed is marital status, which has been shown to be a potential factor related to abuse against older adults ${ }^{4,25}$. In the present study, we found that neglect was $42.0 \%$ more prevalent in older people with partners, in agreement with the 
findings in the literature ${ }^{26}$, a fact that may be the result of a greater burden on caregivers who are seen to have the role of caring for not one, but two older people ${ }^{20}$.

Regarding the characteristics of the aggressor, neglect was three times more likely to be committed by the victim's children, of both sexes, corroborating studies found in international ${ }^{25}$ and national literature ${ }^{8,9}$. Among the reasons pointed out for this relationship is the family context, reinforcing the data above, and often pointed out in the literature ${ }^{18}$ as a stressful environment, with children exercising the role of caregivers, but without the proper preparation for the role, culminating in burden and the consequent neglect of older adults. However, according to Pasinato et al. ${ }^{17}$ this fact is the result of the absence or inefficiency of public policies that support families in caring for older adults, in order to minimize harm caused by conflicts and unpreparedness and interrupt the cycle of abuse.

Regarding the characteristics of the occurrence, neglect was 3.31 times more frequently perpetrated within the residence, similar to results found in the literature ${ }^{8,9,18}$. This finding is mainly justified by observing the age group of older adults, where the victims of neglect are older people with disabilities, who are more often restricted to living with their families $^{8,9,16,19}$.

Psychological abuse and neglect were more prevalent in the group with a history of recurrent abuse, PR: 4.31 and 3.82 respectively. In addition, cases of neglect were not associated with suspected alcohol use and were not motivated by hate. These results are similar to those described by Mascarenhas et al. ${ }^{8}$ and Rocha et al. ${ }^{9}$ when studying the reported cases of abuse against older adults in all regions of Brazil, and return the discussion to the theme of caregivers, since literature ${ }^{16,24}$ shows that the propensity of recurrence in abuse, especially of neglect, is more closely related to signs of burden, such as stress, anxiety and depression, than it is motivated by external causes such as alcohol, for example. It is important to remember that these situations can be alleviated and even avoided with support and assistance programs for these caregivers ${ }^{17}$, which according to Pillemer et al. ${ }^{4}$ have been shown to be effective in preventing the re-victimization of older adults, and have potential to reduce the incidence of this condition.

Regarding the area of occurrence, in both forms of abuse studied, a higher prevalence of occurrence was found in the urban area. This finding reflects the greater agglomeration of people in the urban area than in rural areas, as well as easier access to sectors such as police stations or health facilities ${ }^{22}$, which, in theory, would facilitate reports of abuse in these regions, and also points to the possibility of underreporting of this problem in rural regions.

Given this situation, there is an important challenge that must be faced by health and social assistance professionals, managers, civil society and older adults themselves so that cases of abuse are properly notified. For this to be possible, it is necessary that professionals in different services are trained to identify the possible victims of this disease. Furthermore, it is important that health professionals are aware of the entire care network offered to victims of abuse and their families, so that all necessary care is provided in coping with and preventing new occurrences of this condition ${ }^{13}$.

The present study found important results that can improve the understanding of factors related to the phenomenon of the psychological abuse and neglect of older adults. However, possible limitations need to be considered, such as the analysis of secondary data, where it is common to find inconsistencies. However, an extensive qualification of the database was conducted before the analyzes were carried out. Another identified limitation is the underreporting of cases of abuse, as highlighted in the literature ${ }^{13}$. However, even with these impasses, strong associations were found, that may be even more evident in a greater number of reported cases.

Finally, the cross-sectional nature of the study is also a limitation, making it impossible to establish a causal relationship between the exposure and outcome variables. The importance of this type of study for a better elucidation of the theme is highlighted, however, in addition to its high descriptive potential and analytical simplicity, making it an important support for raising hypotheses and formulating policies. 


\section{CONCLUSION}

From the results presented, it is concluded that the prevalence of reported psychological abuse and neglect was lower than that found in other Brazilian states, and that characteristics of the victim, the aggressor and the occurrence are associated with these forms of harm, in accordance with the type of abuse. Often such abuse is committed in a veiled manner and for this reason remains underreported. There is therefore a need to increase the visibility and discussion of abuse against older adults so that civil society is more aware of this problem, and so that

\section{REFERENCES}

1. World Health Organization. Elder Abuse: the health sector role in prevention and response. Geneva: WHO; 2016.

2. Brasil. Secretaria de Direitos Humanos da Presidência da República. Manual de enfrentamento à violência contra a pessoa idosa: é possível prevenir, é necessário superar. Brasília, DF: Secretaria dos Direitos Humanos; 2014.

3. Lachs MS, Pillemer KA. Elder abuse. N Engl J Med [Internet]. 2015 [acesso em 17 nov. 2019];373(20):194756. Disponível em: https://www.nejm.org/doi/ full/10.1056/NEJMra1404688

4. Pillemer K, Burnes D, Riffin C, Lachs MS. Elder abuse: global situation, risk factors, and prevention strategies. Gerontologist [Internet]. 2016 [acesso em 17 nov. 2019];56(Suppl 2):194-205. Disponível em: https://academic.oup.com/gerontologist/article/56/ Suppl_2/S194/2605277

5. Yon Y, Mikton CR, Gassoumis ZD, Wilber KH. Elder abuse prevalence in community settings: a systematic review and meta-analysis. Lancet Glob Health [Internet]. 2017 [acesso em 17 nov. 2019];5(2):147-56. Disponível em: https://www. thelancet.com/journals/langlo/article/PIIS2214109X(17)30006-2/fulltext

6. Blay SL, Laks J, Marinho V, Figueira I, Maia D, Coutinho ESF, et al. Prevalence and correlates of elder abuse in São Paulo and Rio de Janeiro. J Am Geriatr Soc [Internet]. 2017 [acesso em 17 nov. 2019];65(12):2634-38. Disponível em: https:// onlinelibrary.wiley.com/doi/abs/10.1111/jgs.15106 health professionals are trained to identify, report and deal with this problem, as it is believed that only in this way can the cycle of abuse be broken.

Finally, it is understood that, despite the dissemination of studies on the abuse of older adults in recent years, further studies are needed that analyze their typology separately, as knowledge of these forms of harm in their different manifestations can contribute to the coping with, monitoring and prevention of this phenomenon.

Edited by: Ana Carolina Lima Cavaletti
7. Bolsoni CC, Coelho EBS, Giehl MWC, D’Orsi E. Prevalência de violência contra idosos e fatores associados, estudo de base populacional em Florianópolis, SC. Rev Bras Geriatr Gerontol [Internet]. 2016 [acesso em 17 nov. 2019];19(4):671-69. Disponível em: https://www. scielo.br/scielo.php?script $=$ sci_arttext\&pid $=\$ 1809$ 98232016000400671\&lng=en\&nrm=iso\&tlng=pt

8. Mascarenhas MDM, Andrade SSCA, Neves ACM, Pedrosa AAG, Silva MMA, Malta DC. Violência contra a pessoa idosa: análise das notificações realizadas no setor saúde - Brasil, 2010. Ciênc Saúde Colet [Internet]. 2012 [acesso em 17 nov. 2019];17(9):2331-41. Disponível em: https://www. scielo.br/scielo.php?script=sci_arttext\&pid=S1413 81232012000900014\&lng $=$ pt\&tlng $=$ pt

9. Rocha RC, Cortes MCJW, Dias EC, Gontijo ED. Violência velada e revelada contra idosos em Minas Gerais-Brasil: análise de denúncias e notificações. Saúde debate [Internet]. 2018 [acesso em 17 nov. 2019];42(4):81-94. Disponível https://www.scielo. br/scielo.php?script $=$ sci_arttext\&pid=S0103$11042018000800081 \& \mathrm{t} \operatorname{lng}=\mathrm{pt}$

10. Brasil. Ministério da Saúde, Secretaria de Vigilância em Saúde. Vigilância de violência doméstica, sexual e/ou outras violências: Viva/Sinan - Brasil, 2011. Bol Epidemiol. 2013;44(9):1-12.

11. World Health Organization. Elder Abuse [Internet]. Geneva: WHO; 2018 [acesso em 17 nov. 2019]. Disponível em: https://www.who.int/en/news-room/ fact-sheets/detail/elder-abuse 
12. Instituto Jones dos Santos Neves. Síntese dos indicadores sociais do Espírito Santo. Vitória: IJSN; 2016.

13. Brasil. Ministério da Saúde. VIVA: instrutivo de notificação de violência interpessoal e autoprovocada. Brasília, DF:MS; 2016.

14. Minayo MCS, Souza ER, Silva MMA, Assis SG. Institutionalizing the theme of violence within Brazil's national health system: progress and challenges. Ciênc Saúde Colet [Internet]. 2018 [acesso em 17 nov. 2019];23(6):2007-16. Disponível em: https://www.scielo.br/scielo.php?pid=S1413$81232018000602007 \&$ script $=$ sci_arttext

15. Paraíba PMF, Silva MCM. Perfil da violência contra a pessoa idosa na cidade do Recife-PE. Rev Bras Geriatr Gerontol [Internet]. 2015 [acesso em 17 nov. 2019];18(2):295-306. Disponível em: https://www.scielo.br/scielo.php?pid=S180998232015000200295\&script=sci_arttext

16. Orfila F, Coma-Solé M, Cabanas M, Cegri-Lombardo F, Moleras-Serra A, Pujol-Ribera E. Family caregiver mistreatment of the elderly: prevalence of risk and associated factors. BMC Public Health [Internet] . 2018 [acesso em 17 nov. 2019];18(1):1-10. Disponível em: https://link.springer.com/article/10.1186/s12889018-5067-8

17. Pasinato MT, Camarano AA, Machado L. Idosos vítimas de maus-tratos domésticos: estudo exploratório das informações levantadas nos serviços de denúncia [Internet]. Rio de Janeiro: IPEA; 2006 [acesso em 17 nov. 2019]; (1200):1-36. Disponível em: https://www. nescon.medicina.ufmg.br/biblioteca/imagem/2079.pdf

18. Lopes EDS, Ferreira AG, Pires CG, Moraes MCS, D'Elboux MJ. Elder abuse in Brazil: an integrative review. Rev Bras Geriatr Gerontol [Internet]. 2018 [acesso em 17 nov. 2019];21(5):628-38. Disponível em: https://www.scielo.br/scielo.php?script $=$ sci_ arttext\&pid=S1809-98232018000500628\&lng=en\& $\operatorname{tlng}=\mathrm{en}$

19. Acierno R, Hernandez MA, Amstadter AB, Resnick HS, Steve K, et al. Prevalence and Correlates of Emotional, Physical, Sexual, and Financial Abuse and Potential Neglect in the United States: The National Elder Mistreatment Study. Am J Public Health [Internet]. 2010 [acesso em 17 nov. 2019];100(2):292-7. Disponível em: https:/ajph.aphapublications.org/ doi/10.2105/AJPH.2009.163089
20. Ho CS, Wong SY, Chiu MM, Ho RC. Global Prevalence of Elder Abuse: A Metaanalysis and Meta-regression. East Asian Arch Psychiatry [Internet]. 2017 [acesso em 17 nov. 2019];27(2):4355. Disponível em: https://www.ncbi.nlm.nih.gov/ pubmed/28652497

21. Souza MB, Silva MS, Abreu GS. Violência doméstica entre parceiros íntimos: questões culturais e sociais acerca dos homens autores de violência. Id on Line Rev Mult Psicol [Internet]. 2017 [acesso em 17 nov. 2019];11(38):388-407. Disponível em: http://idonline. emnuvens.com.br/id

22. Bernardino IM, Barbosa KGN, Nóbrega LM, Cavalcante GMS, Ferreira EF, D'Ávila S. Violência contra mulheres em diferentes estágios do ciclo de vida no Brasil: um estudo exploratório. Rev Bras Epidemiol [Internet]. 2016 [acesso em 17 nov. 2019];19(4):740-52. Disponível em: https://www. scielo.br/scielo.php?script $=$ sci_arttext\&pid=S1415790X2016000400740\&lng=pt\&tlng=pt

23. Siqueira CA, Rocha ESS. Violência psicológica contra a mulher: Uma análise bibliográfica sobre causa e consequência desse fenômeno. Revi Arq Cient [Internet] .2019 [acesso em 17 nov. 2019];2(1):12-23. Disponível em: http://arqcientificosimmes.emnuvens. com.br/abi/article/view/107/63

24. Johannesen M, LoGiudice D. Elder abuse: a systematic review of risk factors in communitydwelling elders. Age Ageing [Internet]. 2013 [acesso em 17 nov. 2019];42(3):292-8. Disponível em: https:// academic.oup.com/ageing/article/42/3/292/24179

25. Yan E, Chan KL, Tiwari A. A systematic review of prevalence and risk factors for elder abuse in Asia. Trauma Violence Abuse [Internet]. 2015 [acesso em 17 nov. 2019];16(2):199-219. Disponível em: https:// journals.sagepub.com/doi/10.1177/1524838014555033

26. Wu L, Chen H, Hu Y, Xiang H, Yu X, Zhang T, et al. Prevalence and associated factors of elder mistreatment in a rural community in people's Republic of China: a cross-sectional study. PLoS One [Internet]. 2012 [acesso em 17 nov. 2019]; 7(3): e33857 [10 p.]. Disponível em: https://journals.plos.org/ plosone/article?id=10.1371/journal.pone. 0033857 